\title{
OPRM1 Gene
}

National Cancer Institute

\section{Source}

National Cancer Institute. OPRM1 Gene. NCI Thesaurus. Code C118983.

This gene plays a role in opioid-dependent G protein-coupled receptor signaling. 